\title{
A Study on Green Banking Trends in Uttara Kannada District
}

\author{
C. K. Hebbar \\ Research Professor, College of Management \& Commerce, Srinivas University, Mangalore -575001, India \\ E-Mail:hebbarkc@yahoo.com
}

Area/Section: Business Management.

Type of the Paper: Empirical Research.

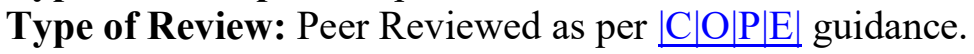

Indexed in: OpenAIRE.

DOI: http://doi.org/10.5281/zenodo.3988880.

Google Scholar Citation: IJMTS.

\section{How to Cite this Paper:}

Hebbar, C. K. (2020). A Study on Green Banking Trends in Uttara Kannada District. International Journal of Management, Technology, and Social Sciences (IJMTS), 5(2), 62-68.

DOI: http://doi.org/10.5281/zenodo.3988880

International Journal of Management, Technology, and Social Sciences (IJMTS)

A Refereed International Journal of Srinivas University, India.

(C) With Author.

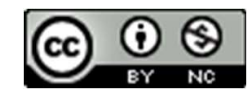

This work is licensed under a Creative Commons Attribution-Non-Commercial 4.0 International License subject to proper citation to the publication source of the work.

Disclaimer: The scholarly papers as reviewed and published by the Srinivas Publications (S.P.), India are the views and opinions of their respective authors and are not the views or opinions of the SP. The SP disclaims of any harm or loss caused due to the published content to any party. 


\title{
A Study on Green Banking Trends in Uttara Kannada District
}

\author{
C. K. Hebbar \\ Research Professor, College of Management \& Commerce, Srinivas University, Mangalore -575001, India \\ E-Mail:hebbarkc@yahoo.com
}

\begin{abstract}
Green Banking has emerged as a new trend of development in response to the current scenario. The concept of 'Green Banking' will be beneficial to the banks, industries, or as well as the economy. 'Green Banking' will not only ensure the greening of the industries but it works in improving the quality of assets in the banks in the future. The data is collected on the basis of both primary as well as secondary data. Finally, "Green Banking" is beneficial for not only the banking sector alone but also to the companies, industries and the whole economy.
\end{abstract}

Keywords: Go Green, Green Debit Cards, RBI, E-banking.

\section{INTRODUCTION :}

In recent days every global leader is telling about global warming and carbon footprint which is affecting the day to day life. It is the responsibility of every individual to contribute to reducing the global temperature to save mankind. Keeping in the mind we would like to introduce a Green Banking system which can contribute to global warming and nature. Green banking gives solutions for paperless business transactions in today's market. Our Prime Minister of India has a vision of digital India in the $21^{\text {st }}$ century, which can be adopted in the banking system by using Green Banking products [1].

\section{CONCEPT OF GREEN BANKING :}

Green banking is one of the activities of the bank in which banks play a vital role between economic growth and environmental protection under this bank takes some action to reduce carbon emissions, this should finance green technology and pollution-reducing projects. Green banking is nothing but a normal bank in which bank takes some initiatives to encourage environmentally friendly investment, which includes social and environmental factors with an aim to protect the environment and natural resources by reducing paperwork in his transaction by this save trees and reduce carbon footprint in the environment [2-5]. Green banking is a new concept of banking where all financial activities remain the same but extra focus is given on environmental protection and sustainability through paperless banking by this save natural resources in nature.

The concept of Green Banking emerged in 2009 with the coming of the first Green Bank based in Mt. Dora, Florida, United States. In India the State Bank of India (SBI), who took initiative in setting high sustainability standards and completed the first step in "green banking" with Shri O. P. Bhatt, chairman, SBI, Inaugurating the bank's first wind farm project in Coimbatore [6]. After that green bank initiative includes ATMs, paperless banking for customers and building of windmills in rural India.

\section{OBJECTIVES OF THE STUDY :}

- To analyze the concept of 'Green Banking'

- To identify the important 'Green Banking' products available in the Uttara Kannada district.

- To study the Green Banking trends in Uttara Kannada district.

- To create awareness about green banking among society as well as bank employees. 


\section{RESEARCH METHODOLOGY :}

The required data for the study are collected from primary as well as secondary data. Primary data is collected from using 90 respondents through direct interviews and using a questionnaire and the secondary data is collected from journals, articles, and websites. For the collection of primary data, respondents are selected based on the random sampling technique.

\section{LIMITATIONS OF GREEN BANKING :}

(1) The findings and recommendations of this study collected based on limited coverage only.

(2) As Green Banking is a recent origin, the reactions or responses based on green banking cannot be accurately measured.

\section{GREEN BANKING PRODUCTS IN UTTARA KANNADA DISTRICT :}

There are several products involved in green banking. They are as follows:-

* Mobile banking:

It is a facility given by the bank to its customers for carrying out financial transactions through mobile phones. It is a new technique and more popularizing today. A customer can make payments like electronic payments, transferring funds and enable to check balance, stop cheque payments, get accounting information, etc through mobile banking. So, the apps in mobile phones help to copy or download electronic statements and thereby reduce the number of papers. It saves time, efforts and energy of prospective customers [7-8].

* E-banking:

Nowadays, E-commerce and the internet is gradually growing. World Wide Web is converting the entire world into the digital world. It offers new techniques for dealing with banking practice. It allows the user that he can access through the banking website and avail of any of the banking sources and functions. It improves the banking relationship and encourage customers and reduces transaction cost at all. It helps the customer to perform easily without visiting banks and it ignores late payment and payment of the bill from home online [9-11].

* ATM:

ATM stands for AUTOMATED TELLER MACHINE. It provides any time money. A customer can withdraw the amount through ATM without visiting the bank branches. It provides a $24 * 7$ service. One can withdraw the amount at any time. This facility is available only in urban areas. So, in the U.K district urban area, people get this opportunity and rural people may not get because of the non-availability of ATM in rural areas [1215].

* Green credit card :

It's a plastic card, which helps the cardholder to purchase goods without making payments immediately. The borrowed amount is like a loan amount and interest is charged for that amount. The main rules followed here is "Buy now, pay later". Bank provides funds to the eco-friendly organizations from every rupee is spent on credit card and it provides a reasonable impact on the protection of the environment [16-18].

* Green Debit Card :

A debit card or bank card is also known as a plastic payment card that can be used for payments when making purchases. In many areas the use of the debit cards has become so widespread they are entirely replacing the facility of cheques and in some cases cash transactions also. Unlike credit card payments, which are made by debit cards are immediately transferred from the designated bank account. The debit card also allows for a quick withdrawal of cash and performs as the ATM cards for withdrawals [19-20].

\section{DATA ANALYSIS :}

The current study is based on green banking trends in the Uttara Kannada district. For this study, data is collected through questionnaires and direct interviews from 90 respondents. That was analyzed in order to draw a certain conclusion in the following manner.

Table 1 : Demographic profile of the respondents 
International Journal of Management, Technology, and Social

\begin{tabular}{|c|c|c|c|}
\hline Demographic Factor & Particulars & Respondents & Percentage \\
\hline \multirow[t]{3}{*}{ Gender } & Male & 35 & 39 \\
\hline & Female & 55 & 61 \\
\hline & Total & 90 & 100 \\
\hline \multirow[t]{5}{*}{ Age } & 21-31 Years & 20 & 22 \\
\hline & 31-41 Years & 38 & 42 \\
\hline & 41-61 years & 18 & 20 \\
\hline & Above 61 years & 14 & 16 \\
\hline & Total & 90 & 100 \\
\hline \multirow[t]{7}{*}{ Education } & Primary & 15 & 17 \\
\hline & High school & 17 & 19 \\
\hline & PUC & 20 & 22 \\
\hline & Graduation & 23 & 26 \\
\hline & Post-graduation & 11 & 12 \\
\hline & Illiterates & 4 & 4 \\
\hline & Total & 90 & 100 \\
\hline \multirow[t]{6}{*}{ Monthly Income } & $0-2000$ & 10 & 11 \\
\hline & $2000-3500$ & 23 & 26 \\
\hline & $3500-5000$ & - & - \\
\hline & $5000-6500$ & 33 & 37 \\
\hline & Above 6500 & 24 & 26 \\
\hline & Total & 90 & 100 \\
\hline
\end{tabular}

Interpretation:

The above table defines the demographic profile of the respondents who are co-operated for this study. On the basis of the above information, we can make an analysis.

Table 2 : Kinds of accounts

\begin{tabular}{|c|c|c|}
\hline Particulars & Respondents & Percentage \\
\hline Saving a/c & 68 & $75 \%$ \\
\hline Fixed deposit & 6 & $67 \%$ \\
\hline Current a/c & 7 & $8 \%$ \\
\hline Recurring deposit & 9 & $10 \%$ \\
\hline Total & 90 & $100 \%$ \\
\hline
\end{tabular}

Interpretation:

As per as above table is concerned it is cleared that out of 90 respondents, 68 are preferred to saving bank account, 6 respondents having fixed deposits, 7 are having current a/c and 9 respondents having a recurring deposit. According to this table, most of the respondents used to prefer saving account.

Table 3 : Usage of green banking service.

\begin{tabular}{|c|c|}
\hline Particulars & Respondents \\
\hline Debit card & 85 \\
\hline ATM & 75 \\
\hline Mobile Banking & 50 \\
\hline E-Banking & 45 \\
\hline Credit card & 20 \\
\hline
\end{tabular}


Interpretation:

From the above table, we can see that majority of the respondents that is 85 respondents are using debit card, 75 are using ATM services, 50 respondents are using mobile banking, 45 are using e-banking, 20 are using credit card, and unexpectedly 10 respondents are not using any of the above services of green banking. It says that all of the respondents were using green banking services effectively.

Table 4 : Banks initiatives towards awareness of green banking is sufficient.

\begin{tabular}{|c|c|c|}
\hline Particulars & Respondents & Percentage \\
\hline Yes & 46 & 51 \\
\hline No & 44 & 49 \\
\hline Total & 90 & 100 \\
\hline
\end{tabular}

Interpretation:

Above the table is defined that $51 \%$ of the respondents say the banks are taking sufficient initiatives towards the awareness of the green banking services and $49 \%$ of the respondents are feels that the banks are not taking sufficient initiatives towards the services of green banking.

Table 5 : Green banking make banking more convenient.

\begin{tabular}{|c|c|c|}
\hline Particulars & Respondents & Percentage \\
\hline Yes & 82 & 91 \\
\hline No & 8 & 9 \\
\hline Total & 90 & 100 \\
\hline
\end{tabular}

Interpretation:

From the above table, it is clear that $91 \%$ of respondents say that green banking would make banking more successful and $9 \%$ of the respondents opined that green banking is not convenient for them.

\section{FINDINGS :}

- This study examines that majority of the respondents having their bank $\mathrm{a} / \mathrm{c}$ and they use to prefer saving bank $\mathrm{a} / \mathrm{c}$ to save their money and for the better convenience.

- From this study, we can find that most of the respondents are aware of green banking services but some of them feel that this system is difficult to operate and not safe and they are having lack information about the usage of this technology.

- By studying this concept, we can find most of the respondents think that green banking would make banking activity more convenient for them.

- Here we can analyze that in the UK district majority of the respondents are not getting accurate 0information about the adoption of green banking practices because the banks are not taking initiatives in these areas to create awareness among these people.

- Finally, we can find there is a Trend on green banking services in UK district

9. SUGGESTIONS :

* The bank must install biometric ATMs in the rural areas to meet the requirements of illiterate customers [21].

* The bank should take up a strong step to create awareness about the availability of green banking services, especially in rural areas [22].

* The bank should arrange a seminar, workshop in the rural areas that should be in the respondent's understandable language. so that customers can get information and it may create interest among those who did not use green banking services [23].

* The government should implement new plans and policies for the popularizing concept of green banking services and practices. 


\section{CONCLUSION :}

Banks are the main source of finance. It plays an important role in economic development. Banks are using a huge quantity of papers to prepare reports, statements which emit carbon cause pollution. Pollution harm the health and wealth of the economy. To remove these obstacle banks undertaken several initiatives green banking strategy to work towards the global environment. In this way, the Indian banking sector implemented several sustainable projects that could accelerate innovative products or services in the area of green banking [24]. It reduces the paperwork and encourages to the e-transaction. It contributes a lot to the environment. So, this technique adopted by banks of U.K. Districts banks which enables fast work and conserves time and efforts and also makes a healthy environment condition by minimizing carbon emissions .so other banks also including these green steps.

RBI and the Indian Government should play a pro-active role in formulating green policy and practices. However, the green strategy brings more awareness about global warming and it is a good way of development [25]. So, finally, the concept of green banking is beneficial for not only the banking sector alone but also to the companies, industries and the whole economy. it is a path towards implementing quality of banking activities.

\section{REFERENCES :}

[1] Page, S. A. and Jones, C. R. (1989). Business Growth: How to achieve and sustain it. Leadership and Organisation Development Journal, 10(2). 1-6.

[2] Choi, Y. (1994). A Green GNP Model and Sustainable Development. Journal of Economic Studies, 21(6), $37-45$.

[3] Elkington, J. (1994). Towards the Sustainable Corporation: Win-Win-Win Business Strategies for Sustainable Development. California Management Review, 36(2), 90-100.

[4] Anitha, B. And Rao, S.P. (1998). Quality of Work Life in Commercial Banks. Discovery Publishing House.

[5] Charlier, H. R. (2000). From Green to Brown: Is Brownfields use Risk Taking. Environmental Management and Health, 11(1), 20-26.

[6] Bahl Sarita (2012). Green Banking- The New Strategic Imperative. Journal of Asian Research Consortium, 2(2), 176-185.

[7] Gibbs, D. and O’Neill, K. (2012). Green Entrepreneurship: Building a Green Economy? - Evidence from UK. Contemporary Issues in Entrepreneurship Research. 2(1), 75-96.

[8] Rouf, A. K. (2012). Green Microfinance promoting Green Enterprise Development. Humanomics, 28(2), $148-161$.

[9] Bhardwaj B. R and Malhotra A. (2013). Green Banking Strategies: Sustainability through Corporate Entrepreneurship. Greener Journal of Business and Management Studies, 4(1), 180-193.

[10] Jha, N. \& Bhome, S. (2013). A study of green banking trends in India. Abhinav, 5(2), 127-132.

[11] Nishant Jha and Shraddha Bhome May (2013). A Study of Green Banking Trends in India. ABHINAV International Monthly Refereed Journal of Research in Management \& Technology, 2, 127-131.

[12] Chaurasia Kumar Ashis (2014). Green Banking Practices in Indian Banks. Blue Square Publishing House, 1(1). 41-54.

[13] Komal Singhal, Krishna Singhal \& Monika Arya (June 2014). Green Banking: An Overview. Asian Journal of Multidisciplinary Studies, 2(6), 196-200

[14] Pratiksha, C. Khedekar (2014). Banking with Technology-Green Banking. Renewable Research Journal, 
3(1), 167-170.

[15] Saleuddin, R. (2014). Reputation Risk Management in Financial Firms : protecting some small investors. Journal of Financial Regulation and Compliance, 22(4), 286-299.

[16] Sharma N, Sarika, K and Gopal R. (2014). A Study on Customer's Awareness on Green Banking Initiatives In Selected Public And Private Sector Banks With Special Reference To Mumbai. IOSR Journal of Economics and Finance, 2(1),28-35.

[17] Ahuja Neyati (2015). Green Banking in India: A Review of Literature. International Journal for research in management and pharmacy, 1(4), 11-16.

[18] LalonMozib Raad (2015). Green Banking: Going Green. International Journal of Economics-Finance and Management Sciences, 3(1), 34-42.

[19] Roux, M. (2015). Finance Otherwise: The End of Banks? International Symposia in Economic Theory and Econometrics, 24(1), 517-536.

[20] Al-Tekreeti, S. M. and Beheiry, M. S. (2016). A Decision matrix approach to Green Project Management Processes. World Journal of Science, Technology and Sustainable development. 13(3), 174-189.

[21] Hebbar, C. K., \& Mahale, P. (2019). Impact of Demonetisation on Green Banking. Global Journal of Management and Business Research, 19(4), 41-45.

[22] Bonin, H. (2016). Colonial and Imperial Banking History. Routledge Publications.

[23] Mahesh, A.C, Nirosha, M. and Pavithra, V. (2016). Recent Trends in Indian Banking-Green Banking Initiative in India. International Journal of Science Technology and Management, 5, 369-374.

[24] Aithal, P. S., \& Jeevan, P. (2016). How Service Industries Can Transform themselves into Green Business Industries. International Journal of Management Sciences and Business Research, 5(4), 1-9.

[25] Aithal, P. S. (2016). Ideal Banking Concept and Characteristics. International Research Journal of Management, IT and Social Sciences (IRJMIS), 3(11), 46-55. 